\title{
Leaving Home: Yemeni Students Discuss Study Abroad Migration
}

\author{
Howard Lorne Martyn ${ }^{1}$ \\ ${ }^{1}$ School of English for International Business, Guangdong University of Foreign Studies, China \\ Correspondence: Howard Lorne Martyn, School of English for International Business, Guangdong University of \\ Foreign Studies, China. E-mail: howardeap@gmail.com
}

Received: April 18, 2019

Accepted: May 1, 2019

Online Published: May 29, 2019

doi:10.5539/ach.v11n2p38

URL: https://doi.org/10.5539/ach.v11n2p38

\begin{abstract}
The decision to migrate for educational purposes is often stressful, but for those leaving countries embroiled in major warring conflicts, the decision may be overshadowed by feelings of sadness, anger and loss. And for many, the ostensible purpose of migration - education, is overshadowed by the desire or need to leave for economic and security reasons. In such situations, migrants hope they can power through those negative feelings and emerge successful, and with familial honor intact. The narrative weapon used to defeat negative feelings are stories of pride and resourcefulness. In this study Yemeni students studying at a university in Guangdong Province, China were interviewed concerning their decisions to leave Yemen. Participants were between 20 and 30 years old: all were male. Most hailed from Aden or Sana'a or areas adjacent to those major cities and all aligned themselves with pre-1990 South Yemen, as described by their fathers. Narrative analysis revealed a striking similarity: stories of hopeful future redemption through economic opportunities found abroad. Indeed, participants revealed a consuming desire for economic success - an obligation that was energized by feelings of pride in being trusted with custodial duties of familial honor. The results are discussed qualitatively in terms of categorical content and episodic form. This study is limited in that it only includes Yemeni males aligned with pre-1990 South Yemen, and those who hail from Sana'a, Aden or nearby urban centers. Future studies should include women, and those who encompass wider political views and reside in rural areas.
\end{abstract}

Keywords: Yemeni Migrants, Narrative Inquiry, Content Analysis, Episodic Form Analysis

\section{Introduction}

Yemen has a long standing tradition of vibrant trade relations in the Middle East, and more recently in Europe and Asia; this has continued to the present time and provides historical underpinnings for migration. Throughout the $17^{\text {th }}$ and $18^{\text {th }}$ centuries India, Iran, Britain and Holland moved coffee, tea and spices through the port of Mocha, a major trading hub and tax collection point for sea traffic from the Middle East, to Europe from the $16^{\text {th }}$ to the $18^{\text {th }}$ centuries (Gopal, 2016). Yemeni traders opened up overland trade routes to Jeddah, avoiding the shallow waters, adverse winds and pirates that sometimes came with routes through the Red Sea. At the beginning of the last century, in the waning days of the Ottoman Empire, the crushing weight of violence and poverty contributed to negotiations in a new era of trade reforms in the Middle East. Yemen stood at the edge of these trade reforms, with Aden, governed as part of British India, standing at the junctures of communication and transportation between the Suez Canal, Mumbai and Zanzibar. A new wave of technology and construction brought about through the Hejaz Railway, running from Medina to Damascus, along with the Suez Canal, facilitated trade and the spread of Yemeni culture north through the region and into Eastern Asia (Blumi, 2003). This leap into modernity engendered a deep cultural crisis.

Cultural and historical forces leading to the dislocation and uprootedness of entire populations in late modernity have, to an extent, lead to a crisis in psycho-social identity. Hammack (2008) believes that identity is formed by cognitive, social and cultural phenomenon that together "are manifest in a personal narrative constructed and reconstructed across the life course, and scripted in and through social interaction and social practice" (pp. 222-225). Such narratives often reveal "contested collective meaning [whereby] individuals may be motivated to adopt an identity that preserves a sense of ontological security that minimizes existential anxiety" (pp. 222-225). The strength of that motivation is influenced by psycho-social necessity, often accompanied by a personal need to find fulfillment through education or work. In the case of individuals struggling through personal or social disruption, a change of physical surroundings from areas of social upheaval to areas of relative tranquility, accompanied by hopes of future financial wellbeing may enable not only minimization of anxiety, but bring 
renewed hope for a meaningful and rewarding future: enrolling in study abroad programs is the initial route many select.

Educational migration has traditionally flowed from less-developed to more highly developed countries; from the educational periphery to the educational center (Altbach, 2007). Organization for Economic Co-operation and Development numbers indicate an overall increase in migrant students from about 3 million in 2005, to about 4.5 million in 2015, with $73 \%$ (2015) studying in OECD countries, primarily the European Union, the United States, the United Kingdom and France. Students from Asia accounted for 53\% of study abroad students, and of those, $22 \%$ hailed from China, the largest share among reporting countries. China is unique in that its acceptance of foreign students has also been rising dramatically, from approximately 250,000 in 2009 to 442,000 in 2016 , over $2 \%$ of the worlds tertiary international student population (OECD, 2016). China has become both the largest supplier of foreign students in the world, and the 2nd largest destination for foreign university students, after Japan, in Asia. Indeed, China's Ministry of Education, in 2015, proposed raising the then number of international students in the country from 398,000 to 500,000 by 2020 (Wen \& Hu, 2018). According to the Ministry of Education (2018), it has largely succeeded in that goal, with 489,000 as of 2017.

Many of these students hail from areas of disadvantage, relative to China, and this situation is likely to continue. Given this increase in student migration, China's educational systems are likely to come under increasing strain due to psycho-social, cross-cultural, and financial life goals of foreign students. There is a dearth of research concerning psycho-social stresses of Yemeni university students in China. A crucial preliminary step in mitigating potential conflict is to understand the backgrounds of migrant students; the current narrative study contributes toward that first step.

Although Yemeni students make up a very small percentage of the international student population in China they disproportionally come from chaotic societal and educational environments. Indeed, between 2015 and 2018 half a million high school students dropped out of school, in a country where less than $50 \%$ of eligible primary/high school aged students are actually enrolled. That dropout rate rose to 2 million in 2018 in part due to a lack of teachers; $67 \%$ of public school teachers have not been paid for two years, causing a dramatic teacher exodus (UNICEF, 2018). Fewer than 10 percent of students who graduate from high school pursue university education. In 1997 there were about 53,000 students in Yemen's seven universities, but through massive government expenditure and promotion that had risen to about 185,000 by 2006 (The World Bank, 2008). The ongoing war has caused a reversal of that trend, with the World Bank describing the near future economic prospects as "grim" (The World Bank, 2015, p. 15), and contributing to a rapid decline in the economy, with a knock on effect in tertiary education. A study by Mohammad Al Soofi, a professor of education at Sana'a University found that dozens of university building have been completely destroyed due to the war. Professors have not been paid in months, most students cannot pay fees, and dropout rates in 2018 were about 50\% (Darem, 2018). Many students who are financially able to consider university realize that their educational and job prospects are likely enhanced by overseas study.

China has been increasing its placements and scholarships for Yemeni students. In 2010 it initiated its "Study in China Program", encouraging Yemeni, and other international students, to consider China as an educational destination. That program was further propelled by the country's drive in educational development through the aggressive "Double First Class" initiatives begun in 2015 (Peters \& Besley, 2018). This has resulted in increased enrollment of foreign students, many from developing countries, including Yemen.

\section{Narrative Inquiry}

Lodi-Smith, Philipe and Houle (2016) suggest that individual's life stories ought to be understood as core elements of personality that are associated with psycho-social well-being; narratives provide clear predictors of contentment which includes satisfaction and success in chosen endeavors. Importantly, they stress that the creation of meaning from narratives assists in the formation of personal identity, thereby assisting in the creation of a sense of purpose.

Roxana Waterson (2007) believes that narrative methodology is a greatly under-utilized research tool within the social sciences, due in part to the fuzziness concerning how to present and analyze records of personal historical experiences; perception is fuzzy and open to wide interpretation. Nevertheless, having engaged in narrative methodology for over 40 years, she believes its strength and weakness are one in the same, lying in the uniqueness of personal voice - usually multiplied countless times by those who have gone through similar experiences. In countries such as Yemen where it is common for individuals, even of a relatively young age, to have lived through several distinct regimes with conflicting requirements, lives become fractured by competing values and alliances. Narrative inquiry, at its core, is concerned with revealing these fractures and how they have 
impacted individuals.

While in the early years of narrative data collection there was a preoccupation with identifying 'typical' lives (e.g. Malinowski's study of spiritualist practitioners (Note 1), that rationale has been augmented. Hoskins (2007) feels that, even within a homogeneous society, it is the uniqueness of perspectives, or engagement with the breadth of perspectives that provides insight, and that this breadth of perspective may be demonstrated in a variety of ways, which the narrative researcher should be aware of when collecting and analyzing data. Some of these include genre, the politics of public and personal memory, and views/remembrances that oppose those considered historically accurate.

Genre may include songs, poems, storytelling, acting or reference to objects held or discussed by participants. Heirlooms, weapons - especially if used in combat, and articles of personal religious significance are sometimes used as a focus for discussion. Often discussion centers on the perceived life quality enhancement, or the ability to triumph over adversity that the object has afforded the participant. Hoskins (2007) advises that personal triumph against adversary - "the Horatio Alger story genre in American culture, where a young hero strives against adversity to achieve fame and fortune" (p. 93), occasionally surfaces in personal narratives. In terms of the politics of memory, Hoskins (2007) indicates that researchers should be aware of the sometimes quickly changing features of societal power relations and the effect that these may have (or not have) on the relaying of events. This is particularly important where participants futures may be influenced by governments or cultures sensitive to adverse comments. Individual experiences and views do not necessarily represent what is often taken to be the wider historically accepted view of events. Hoskins (2007) draws our attention to the fact that one can experience success and prosperity in the midst of cultural deprivation and chaos. Such narratives serve to highlight the uniqueness of individual lives.

Polkinghorne (1988) describes the ideal narrative as a "gathering of events into a meaningful story ... through which life events are conjoined into coherent, meaningful, unified themes" (pp. 126, 131). He points out that narration should be more than simply a recording of events; or more even than a recording of events with analysis. It is the creation of personal identity, the construction of events, and perhaps most importantly, the allocation of merit or noteworthiness. Clandinin and Connelly's (2000) simply put truism provides the grounding: "Why narrative? Because experience" (p. 50). Clandinin and Connelly (1994), expanding on Dewey's belief that narratives must be contextualized within situation, continuity and interaction, feel that narratives should also reach inward to our hopes, feelings, aesthetic and moral values; in effect establishing the locus of identity control, as well as extending outwards, affecting the reader and in so doing create the possibility for social transformation. Narratives are bound to memory and are thus temporal, just as they are bound to place. While economic, political and social forces have come together at a given place and time to make migration the clear alternative for those living through upheaval, those forces always bring about discontinuity, dislocation and uprootedness. They strain relationships and tests moral values. Economic and social injustices often precipitate. Common memory, revealed through narratives of time and place, reveal injustices and form catalysts for the embarkation into new lifeways designed to recapture agency, relocating it within the individual, a process "likely to invoke strident forms of reawakening" (Niezen, 2004, p. 40).

The examples below illustrate themes of disruptive pasts, negotiation with family members, searching for independence through education and work, and developing possibilities for future education and employment. These themes dominated participant discussions, and were placed within past, present and future timeframes. The written narratives in the remainder of this paper are authentic. Word choice and grammatical changes have been made only when clarification is necessary.

\section{Method}

I employ a social-constructivist narrative approach to data collection. Such inductive methodologies are utilized to avoid the binary dichotomies typically found in positivist statistical research. People's storied lives become prominent: we imagine a face, rather than see a statistic. Narrative data collection is often the method of choice when the researcher wishes to allow the participant maximum unrestricted expression, or when the participant might wish to control the direction of the interview. For example, Riessman (2015), and Morris (2017) allow participants the narrative latitude to discuss their end of life experiences while undergoing severe illness. Bury (2001) discusses how individuals lose personal identity when undergoing traumatic illness when subsumed into the bio-medical 'grand narrative'. Gray (2001) investigates coping strategies of autistic teenagers and their parents in meeting the challenges of daily life. Clough (2002) and Murray (2010) utilize story-telling and narrative with adolescents suffering from family stress and breakdown. Brante (2012) investigates critical incidents among teachers in abhorrent working conditions, using narrative interviews. Gonzalez-Lopez (2015) 
invokes narrative methodology to examine the effects of psycho-therapy used with adolescents suffering the after-effects of physical abuse. Klots (2011) uses narrative methodology in order to uncover the overt and hidden lives of migrants in the United States. Benish-Weissman (2009) uses narrative interviews as a starting point to discuss immigrant trauma among two dozen Soviet migrants in the Middle East. Martyn (2018a, 2018b) uses a narrative methodology in discussing social action planning in an educational setting among migrant workers in Asia.

Denzin (1989) describes narrative data collection as:

Tales of events that are significant for the narrator and his or her audience. A narrative as a story has a plot, a beginning, a middle and an end. It has internal logic that makes sense to the narrator. A narrative relates events to a temporal, causal sequence (p. 37).

Although narratives may progress from a beginning to an end, structurally, the story itself may follow no particular timeline. Indeed, it may flow forward, reverse, digress, and lurch forward again, uneasily. The narratives in this paper have no endings - they describe lives that are in transition; but transition does not imply limbo. In fact, the participants are moving forward, making plans, preparing for their new lives. Polkinghorne (1995) believes that narratives reveal those who are "attempting to progress to a solution, clarification, or the unravelling of an incomplete situation" (p. 7). Yemenis interviewed in this study certainly fall within that description.

Student assistants, designated by a department in a Guangdong China university, were contacted with requests to suggest a list of students that I could use as contact references. I had specifically asked for a listings of Yemeni students and the assistants supplied me with 'Wechat' contacts. Individual students were contacted and arrangements were made to interview them individually. We met either in a common space on the campus, or at a nearby café. Interviews were recorded and later transcribed with emergent themes and patterns noted. In thematic analysis emphasis lies in the events and their implications for the speaker. As such, 'messy' language is transformed to make it more readable, with care taken not to alter meaning.

Four typical cases are presented. This report focuses on the pre-departure events, attendant preparations concerning the decision to study abroad, and the inherent emotional turmoil involved. Aspects of the interviews involving adaptation to life in China, including successes, frustrations, and building new relationships; and how participants felt their time in China might affect their futures in terms of possible further study, work, family and relationships, will be covered in subsequent reports.

I used an approximation of "convergent interviewing" (Goodley, Lawthom, Clough, \& Moore, 2004, p. 85) in order to organize our discussions into a chronological, biographical account and to allow participants maximum flexibility in answering questions. This was useful in that the interviews were conducted in English; I do not speak Yemeni, nor is my Putonghua adequate for interview purposes. When arranging the interviews some participants expressed concern that their English might not suffice (in fact, we had no difficulty communicating). We started with casual conversation, then moved into the three broad areas noted above, and within these broad areas, narrowed the discussion to specifics when appropriate.

Individuals and groups construct identities through storytelling. Storied construction of the self is necessarily fluid, whereby we are constantly in a fluctuating situation of "being" and "becoming" that varies in intensity and content throughout the storytelling process. There is an aspect of discursively constituted co-construction in interviews, whereby established meaning for the participant, and co-constructed meaning, is sometimes fluid. Riessman (2008) points out that the audience, or interviewer, exerts a crucial influence on this construction - on what can and cannot be said, what can be taken for granted and what needs explaining. In the case of international students there is the often unspoken understanding that they are in their host country as guests and must be respectful in all situations. This can, in some cases, cause a communication barrier - some things are left unsaid.

In transcribing the recordings, I followed Clough's (2002) method of removing myself from conversations, except where a question prompt would add clarification or indicate a change of conversational direction. As in data collection, I employ qualitative analysis.

Lieblich, Tuval-Mashiach and Zilber (1998) classify and organize narratives into two dimensions: holistic versus categorical, and content versus form. Holistic analysis examines life stories as a whole, with sections examined in light of the whole. For example, Clough (2002) examines social and learning disfunctions among youth in disadvantaged areas of England by examining general attitudes and behaviors. Goodley (2004) examines the lives of the cognitively disadvantaged, giving them a public voice with the hope of generating public dialogue 
into their condition; the overall narrative provides insight into specific social disadvantage. Moore (2004) examines the life of a quadriplegic using holistic analysis, with the aim of improving the lives of future sufferers, and documents his decision to commit suicide. Categorical analysis, or traditional content analysis, subdivides text into micro sections - sentences, phrases, individual words which are examined. This is often undertaken to examine a phenomenon affecting a particular group of people. For example, Pavelko and Owens (2017) use sample utterances and grammatical analysis (SUGAR) to examine age related changes in children's abilities to cognitively transcribe and understand utterances. Ladeforged (1988) examines micro-utterances using the International Phonetic Alphabet (IPA) to determine voiced, bilabial and, nasal sounds for insights into the voiced production of English by non-native speakers.

In the current study I select portions of the transcribed narratives that exemplify emergent themes. Life decisions and rationales within these themes are then examined. Thus, categorical content analysis is well suited to the data.

Holistic analysis of form examines narratives in terms of their implied story construction; that is, it takes a literary approach to analysis. Gregen and Gregen $(1986,1988)$ believe that every story can be examined in terms of its plot and can be graphed in terms of progression, regression, stasis or a combination, by examining issues that include hopes for the future, setbacks, illness, wellness, relationships, birth, death and new beginnings. In their book Narrative Means to Therapeutic Ends, White and Epston (1990) take the view that narratives may be used in aid of reassessment of a participants life view, for example from victim of circumstance to hero of his or her own life story. Their view reflects that of, Becker $(1971,1973)$, who believes that self-esteem acts as an anxiety buffer, deflecting the horror of complete self-awareness, by allowing us to become our own hero. Heroic self-esteem mitigates the lethargy and lack of life-control brought about by negative life circumstances. On the other hand, categorical analysis of form examines the complexity of description and arguments - in particular the inconsistencies, inaccuracies or illogical reasoning that may be found in narratives. Linde (1993) describes categorical-form analysis focusing on stylistic or linguistic characteristics - issues such as types of metaphors used and frequency of passive versus active utterances.

In this paper I examine emerging trends in the participants language from the perspective of a modified holistic form analysis - episodic form, which looks at emotional content. This content is then graphed to indicate changes in positive and negative emotion during our conversation.

But it is important to point out that there is much overlap between dimensions. Lieblich, Tuval-Mashiach and Zilber (1998) caution us not to be overly didactic in applying analysis as, "the separation of 'whole' from 'category' is, in reality, not clearer than that between 'content' and 'form"' (p. 169).

\section{Analysis}

\subsection{Jaden: Pre-Departure}

Jaden's (Note 2) family considered sending him abroad since he turned 18, three years ago. Jaden recalled the event that lead to their commitment to his life progress.

McAdams et al. (1997) refers to stories that move progressively toward more situationally and emotionally negative conditions as 'contamination' sequences, while those that take a more positive upward note are referred to as 'redemption' sequences. Such sequences are typically graphed to provide a visual reference. Lieblich et al. (1998) also visually represent sequences that cause an upward, downward or irregular pattern to stories. In my analysis I graph the episodic form, the highs and lows of emotional content present in the telling of the story.

Jaden began our conversation with a dramatic remembrance of waking up early one morning to the sound of exploding bombs. In recounting this, his voice was pitched and his arm and hand gestures animated. This settled into a resignation that, even if the war did not last long, the economic damage would take decades to repair. This contamination sequence was moderated by a more nuanced discussion of Jaden's childhood and his exuberance and pride when discussing his educational achievements, and the unmistakable pride he took in his city and family. The discussion of his missed opportunity to study in France fluctuated between pride, at his educational achievements, and a feeling that, even though studying in France was no longer possible, he had found a way forward through migration to China - a redemptive ending. The progression of Jaden's narrative episodes are graphed below. 
Table 1. Jaden: Pre-departure Analysis

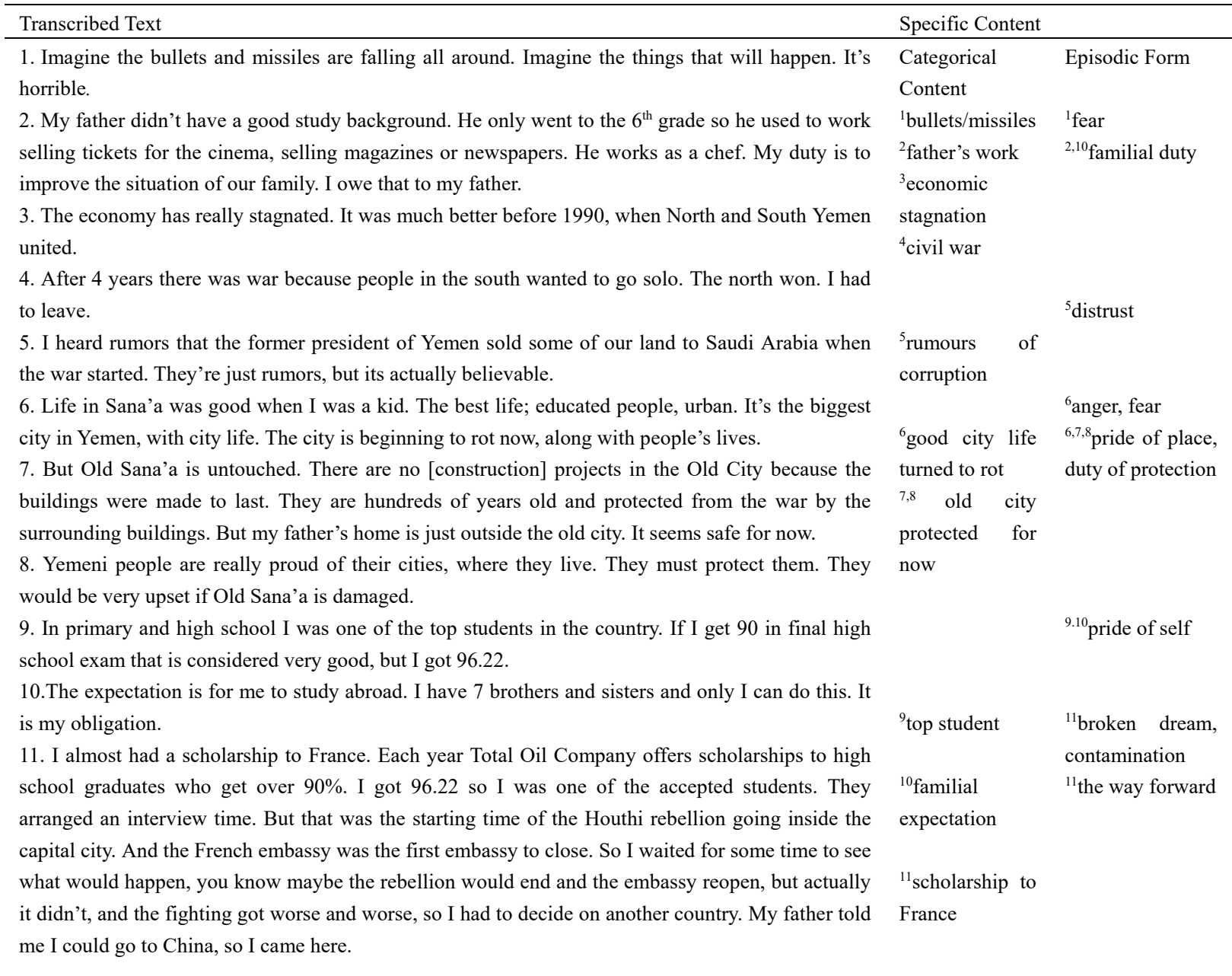

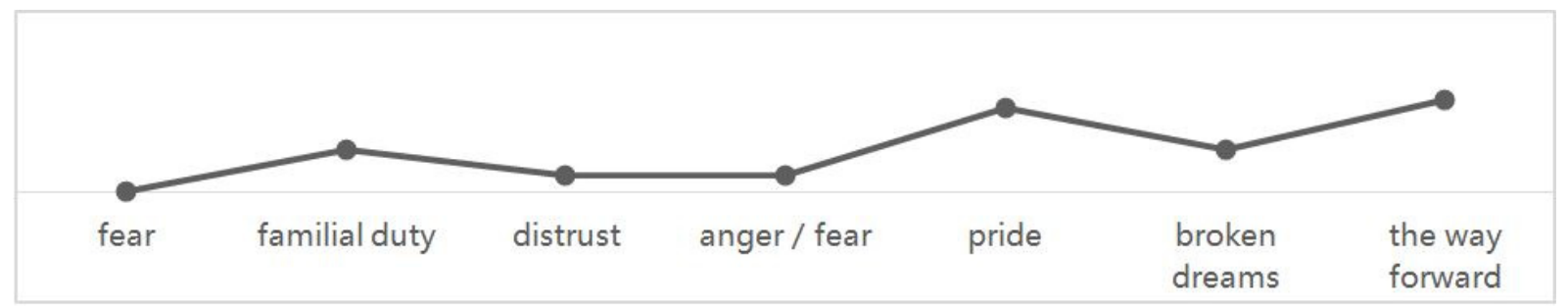

Figure 1. Jaden: Episodic Form

\subsection{Nadheer: Pre-Departure}

Nadheer discussed the need to utilize his training in accounting, for the benefit of his family.

Nadheer immediately drew attention to the war, but unlike Jaden, he did not indicate personal experience with the conflict. His concern centered around how the war had affected the economy and his father's future in clothing design and wholesale. Family duty, and in particular patriarchal duty, was considered very important for all participants. Nadheer clearly viewed his father as a source of inspiration and leadership both artistically and through business - a business that after 20 years was destroyed. Nadheer believed it his duty to assist in rebuilding that business, and regarded the conflicting political aspirations with distain. That distain grew as he continued to consider how his father's financial future was being destroyed. 
Table 2. Nadheer: Pre-Departure Analysis

\begin{tabular}{|c|c|c|}
\hline \multirow{3}{*}{$\begin{array}{l}\text { Transcribed Text } \\
\text { 1. Nowadays in Taizz there is some war, some trouble. Many of the shops have closed. } \\
\text { 2. I was in an international school; did my Cambridge exams. I was concentrating on } \\
\text { business and hoped to work for my father, to become his accountant one day. Sadly, } \\
\text { impossible at the time. }\end{array}$} & \multicolumn{2}{|c|}{ Specific Content } \\
\hline & Categorical Content & Episodic Form \\
\hline & $\begin{array}{l}{ }^{1} \text { some war, some trouble } \\
{ }^{2} \text { studied business }\end{array}$ & $\begin{array}{l}2,3 \text { crushed hopes } \\
3,5,6,7,8 \text { pride in father }\end{array}$ \\
\hline $\begin{array}{l}\text { 3. When my father was young he studied clothing design, then opened his own retail shop } \\
\text { and eventually started selling wholesale. That was my desire also, but again I was } \\
\text { prevented. }\end{array}$ & $\begin{array}{l}{ }^{3} \text { father studied clothing } \\
\text { design } \\
{ }^{4} \text { artistic aspects of design }\end{array}$ & ${ }^{4}$ pleasure of recall \\
\hline $\begin{array}{l}\text { 4. He still works in clothing design, and loves the artistic aspects of design - you know, the } \\
\text { entire presence of any person, man or woman, can be altered by a simple design } \\
\text { element. }\end{array}$ & ${ }^{5}$ father's design & $\begin{array}{l}{ }^{5,6} \text { duty and desire } \\
\text { to help father }\end{array}$ \\
\hline 5. My father was very aware of the impressions particular clothing designs bring out. & knowledge & ${ }^{7}$ hope for the \\
\hline $\begin{array}{l}\text { 6. It is my duty and my desire to help my father in his design work but I am very good with } \\
\text { numbers. }\end{array}$ & ${ }^{6}$ very good with numbers & future \\
\hline 7. I think accounting is where I can really assist his business. & ${ }^{7}$ accounting & ${ }^{8}$ anxiety for future \\
\hline $\begin{array}{l}\text { 8. Most of the big traders in Taizz bought from my father. He had a successful business for } \\
\text { about } 20 \text { years. But then the war came - we lost so much. Now I don't know. }\end{array}$ & ${ }^{8}$ success and loss & $\begin{array}{l}{ }^{9} \text { conflicts of } \\
\text { national loyalty }\end{array}$ \\
\hline $\begin{array}{l}\text { 9. Taizz has suffered so much because of its location. You know, it is not firmly in the south } \\
\text { or the north but sits between the two locations. So we have citizens who say, "oh, we } \\
\text { must be with the south because it is progressive." And we have citizens who say, "no, it } \\
\text { is the north that needs our assistance." This is really terrible. You need to keep quiet and } \\
\text { mind your own business. But how can you make progress living like that. }\end{array}$ & $\begin{array}{l}{ }^{9} \text { how can you make } \\
\text { progress } \\
{ }^{10} \text { power, wealth, } \\
\text { infrastructure }\end{array}$ & $9,10,12,13$ anger \\
\hline $\begin{array}{l}\text { 10. The main thing is power and wealth. People in the north feel they lack political power. } \\
\text { 11. The south has the oil and the seaports and better infrastructure. The south was developed } \\
\text { under the British and later under the Soviets, so it was comparatively well off. Aden is a } \\
\text { British built port, and from there you can control shipping throughout the Middle East. } \\
\text { That is where the economic power lies. }\end{array}$ & $\begin{array}{l}{ }^{12} \text { Houthis looking to } \\
\text { control } \\
{ }^{12,13} \text { foreign power } \\
\text { involvement }\end{array}$ & ${ }^{11}$ pride of place \\
\hline $\begin{array}{l}\text { 12. The Houthis, mostly in the north, try to get power from Iran. They are really looking to } \\
\text { control the entire country, even though they are just a small minority. }\end{array}$ & $11,13,14$ financial disaster & \\
\hline 13. Saudi Arabia's involvement in this issue is causing a financial headache. & & \\
\hline $\begin{array}{l}\text { 14. You can't progress while you live in Yemen. It has been a financial disaster for my } \\
\text { father. }\end{array}$ & & ${ }^{14}$ concern for father \\
\hline
\end{tabular}

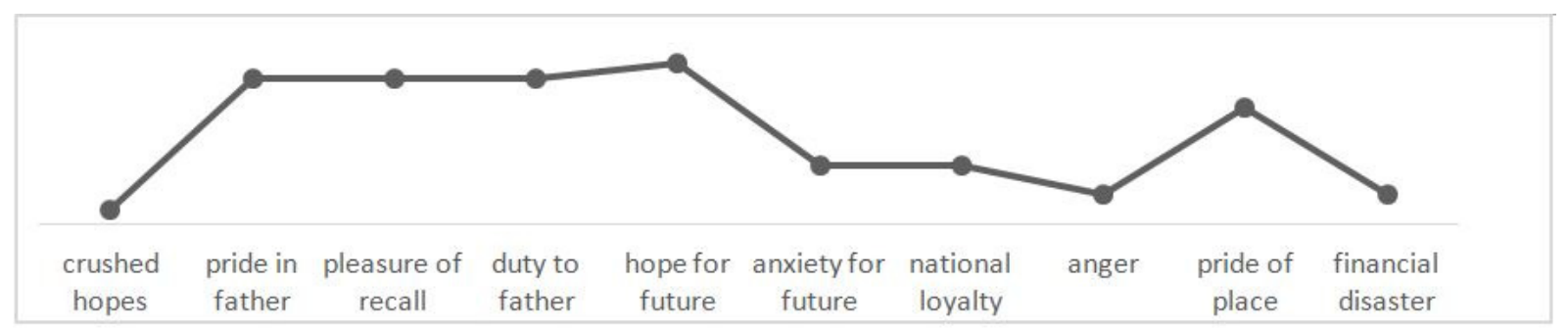

Figure 2. Nadheer: Episodic Form

\subsection{Yasser: Pre-Departure}

Yasser discussed intolerable regressive national manipulation by politicians, leaving departure the only option for personal progress.

Yasser's recollections went from sadness to anger as he considered how the past prosperity of his home city, Aden, had been destroyed by those from the former North Yemen. He regarded the development potential of North Yemen as very low, and believed it would be a financial burden to those in the south, and especially Aden, which he regarded as a previously "wonderful city". He feared that the country would never regain its pre-1990 prosperity. When discussing Aden, his fathers and his uncles, Yasser exhibited a great deal of pride, exemplified by his father's trust and reliance, manifest in the words, "you are a man, so you do it"! 
Table 3. Yasser: Pre-Departure Analysis

\begin{tabular}{|c|c|c|}
\hline Transcribed Text & ntent & \\
\hline $\begin{array}{l}\text { 1. Aden was a very prosperous city before } 1990 \text {, when North and South Yemen united. } \\
\text { Northern Yemen wished to unite because of the oil in the south. Before } 1990 \text { the south was } \\
\text { prosperous, with only } 2 \text { or } 3 \text { million people, compared to } 18 \text { million in the north. } \\
\text { 2. We had socialism supported by the Soviet Union and a better quality of life - good } \\
\text { healthcare, good education, strong economy with good salary. Now we've got shit. }\end{array}$ & $\begin{array}{l}\text { Categorical Content } \\
{ }^{1} \text { pre-war prosperity } \\
{ }^{2} \text { now we've got shit }\end{array}$ & $\begin{array}{l}\text { Episodic Form } \\
{ }^{1,6} \text { sadness } \\
{ }^{2,3,6,7} \text { anger }\end{array}$ \\
\hline $\begin{array}{l}\text { 3. Can you imagine what happens when you let } 18 \text { million barbarians into a small prosperous } \\
\text { area with only } 3 \text { million? }\end{array}$ & $\begin{array}{l}\text { barbarians } \\
\text { unities }\end{array}$ & \\
\hline $\begin{array}{l}\text { 4. My father got scholarship to Russia. He was there } 8 \text { years and got a master's degree in } \\
\text { Aircraft Engineering. He was just a guy from the countryside, but he had that opportunity. }\end{array}$ & $\begin{array}{l}{ }^{5} \text { British built Aden into } \\
\text { a wonderful city }\end{array}$ & $\begin{array}{l}{ }^{4} \text { pride } \mathrm{i} \\
{ }^{5} \text { pride } \mathrm{i}\end{array}$ \\
\hline $\begin{array}{l}\text { 5. Our colonizers were British. They built Aden into a wonderful city. } \\
\text { 6. Our present life situation and education came from after } 1990 \text {. We didn't find any good } \\
\text { situation for the whole country. It's just like wars, inflation, poverty. } \\
\text { 7. The Yemeni people are being manipulated by politicians. }\end{array}$ & $\begin{array}{l}{ }^{6} \text { wars, inflation, } \\
\text { poverty } \\
{ }^{7} \text { manipulated by } \\
\text { politicians }\end{array}$ & $\begin{array}{l}{ }^{5} \text { admiration for } \\
\text { colonizers }\end{array}$ \\
\hline $\begin{array}{l}\text { 8. I have } 7 \text { uncles. Five of them studied outside: Russia, Germany, Bulgaria, Cuba. They all live } \\
\text { abroad now. I majored in accounting. I'm an accountant. My mother don't want me to go } \\
\text { abroad but my father say, 'you are a man, so you do it!' My father tell me that the family's } \\
\text { future is in China, and we can study and work here together. }\end{array}$ & $\begin{array}{l}{ }^{8} \text { uncles studied abroad. } \\
\text { 'You are a man, so you } \\
\text { do it!' }\end{array}$ & $\begin{array}{l}{ }^{8} \text { pride in father } \\
\text { and uncles }\end{array}$ \\
\hline
\end{tabular}

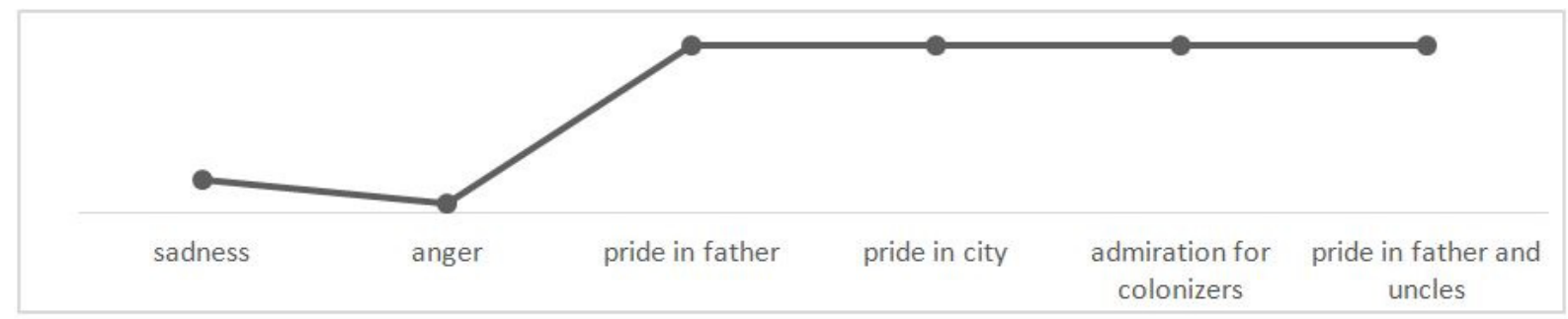

Figure 3. Yasser: Episodic Form

\subsection{Hussein: Pre-Departure}

Hussein discussed the need to avoid financial ruin and find economic stability, which has required a transient lifestyle for his family.

Hussein began by commenting on his father's decision to relocate the family to Saudi Arabia, 26 years ago. He believed this was a momentous and brave decision, taken to avert financial catastrophe - and even more auspicious, given that his mother was pregnant with him at the time. Hussein exhibited a very high degree of admiration for his father, particularly in his father's tenacity in earning a living, no matter what the situation, or where he had to go to succeed. When Hussein discussed political and economic situations that threatened the family, these seemed to serve as vehicles by which he could interject comments about the resourcefulness of his elder male relatives.

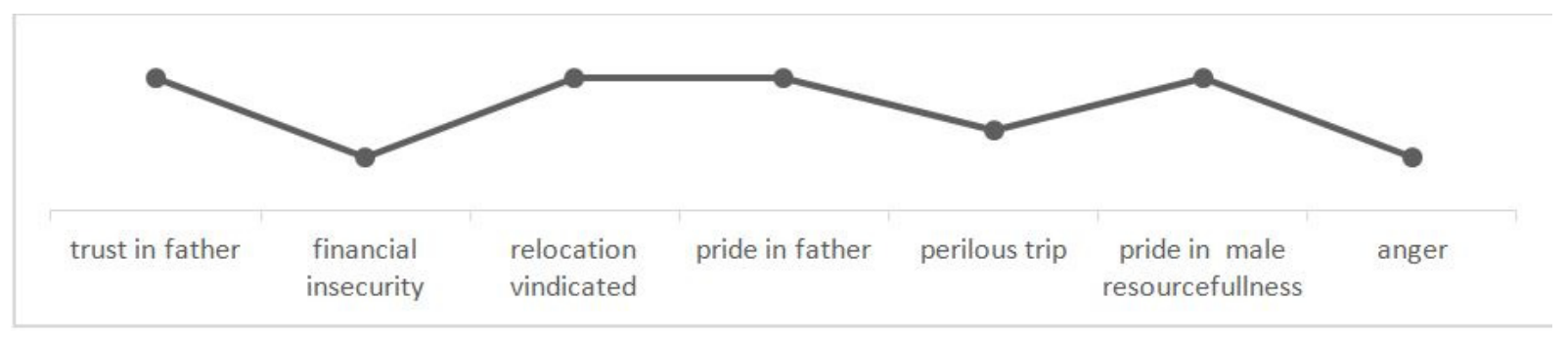

Figure 4. Hussein: Episodic Form 
Table 4. Hussein: Pre-Departure Analysis

\begin{tabular}{|c|c|c|}
\hline Transcribed Text & Specific Content & \\
\hline 1. I live in Jeddah, Saudi Arabia. I have been there my whole life. Actually, my father began & Categorical Content & Episodic Form \\
\hline looking into a move to Saudi Arabia about 40 years ago. & ${ }^{1}$ father took family & ${ }^{1}$ trust in father \\
\hline 2. No matter how you build your business up, it might crash down in one month's time. & to Saudi Arabia & ${ }^{1,2}$ financial \\
\hline 3. My father's business in Saudi Arabia is doing well now. & ${ }^{2}$ it might crash & insecurity \\
\hline 4. My whole family move there 26 years ago. At that time my mother was pregnant with me. & down & ${ }^{3}$ relocation \\
\hline 5. My father and uncle are in the clothing business together. They move to wherever they get & ${ }^{3}$ father's business & vindicated \\
\hline the best price; Thailand, $\mathrm{Ir}$ & doing well & ${ }^{3}$ pride in father \\
\hline why I'm in China. & ${ }^{4}$ mother & ${ }^{4}$ perilous trip \\
\hline $\begin{array}{l}\text { 6. The border was very open. But that has changed dramatically. The Yemeni and Saudi markets } \\
\text { are more separate with guards stopping and searching, stopping and searching, taking anything } \\
\text { that they do not want you to carry across. In this situation a decision has to be made: Should we }\end{array}$ & $\begin{array}{l}\text { pregnant with me } \\
{ }^{5} \text { move wherever } \\
\text { they get best price }\end{array}$ & $\begin{array}{l}{ }^{5,6} \text { pride in male } \\
\text { resourcefulness }\end{array}$ \\
\hline remain in our home country or live across the border. We cannot easily have it both ways. & ${ }^{6}$ remain in our & \\
\hline 7. When we had North Yemen and South Yemen the economic situation was much more stable. & home country or & \\
\hline South Yemen is rich in oil resources, North Yemen rich in agriculture. They complemented each & live across the & ${ }^{7}$ anger \\
\hline other, but of course South Yemen was much richer. But when the countries united in 1990 it & border? & \\
\hline created havoc, leading to the civil war in 1994 . The military leaders from the $n$ & ${ }^{7}$ civil war havoc & \\
\hline oint the Houthis, with money from Iran, instigated a & ${ }^{7}$ involvement of & \\
\hline & & \\
\hline
\end{tabular}

\section{Discussion}

Yemen has a vibrant centuries old history of trade throughout the near and middle east and reaching into China and the far east in more recent times. Historic trade routes along with their associated economic concerns have recently been severely disrupted, leading to economic and social turmoil, limiting education and casting families into unknown futures. Families undergoing anxiety brought about by dislocation and uprootedness will often seek future-affirming steps which at least appear to offer hope in times of chaos. Such hopes often reside with older male children who become custodians of the family's future.

Although migration for education or work has typically flowed from less-developed to highly developed countries, procedures are long, cumbersome and offer no certainty. For Yemeni students, China offers a swifter, more cost-effective alternative with good alignment in terms of trade.

Yemeni students at a university in Guangdong Province discussed aspects of their lives, propelling them to seek education in China. In discussions they often exhibited the highs and lows of individuals undergoing rapid shifts in living arrangements and cultural adjustments. These are visually represented in episodic form graphs, which present attitudes and emotional expressions which change from moment to moment depending on the subject under discussion. Jaden began his discussion with a description of waking up at night to the sounds bullets, missiles and bombs - fear was evident. After some time when discussing a failed bid to become a scholarship student in France, his mood inched into unhappiness, but some minutes later, when elaborating on his current experiences in China, he clearly felt a sense of pride in discovering the way forward; or, in other words, his narrative went from "contamination" to "redemption" (Adler et al., 2017; Benish-Weisman, 2009; Lieblich et al., 1998; McAdams, Josselson, \& Lieblich, 2001). Nadheer also began by talking about the war, especially in terms of how it had crushed people's dreams, but he quickly moved on to discussing his duty in assisting his family, and especially his father, in securing their future. But he also realized that regardless of how hard he and his father work, they are unlikely to overcome national turmoil that has ruined the economy. In the end, as shown in his episodic graph, he ended our conversation at about the same contaminated level. Yasser began by discussing how the country had changed from pre-1990 to the present. He was both sad and angry, feeling that the economic downfall was due to ill-considered political decisions. His mood picked up quickly when discussing his father and uncles, the wonderful historical aspects of Yemen, and even the British and Russian colonizers. Our discussion ended well, with Yasser quite convinced that he could succeed and bring honor to the family. Hussein's father had made a critical decision to move the family to Saudi Arabia, where Hussein was born. Hussein expressed unreserved trust in his father's decisions and later, extended that to his uncles. He spoke with a great deal of pride about the virtues of male intrepidity and resourcefulness. This was a theme common to all participants. 


\section{Conclusion}

Identities are often contingent upon performance. It is through performance that we attribute importance and make known what we believe to be true. In discussions with Yemeni university students, it is clear that the tribulations brought about by war and financial devastation have been catalysts for personal growth. Fathers, along with uncles and other elder male family members, have been the propellants pushing these students toward successfully coping with whatever adversity comes their way. It is clear that participants are highly motivated toward economic success, and that this drive comes from older male family members in whom participants exhibit a great deal of pride and affection.

Interestingly, though Yemen is currently undergoing one of the most destructive wars of this century, in terms of human suffering and death, none of the participants alluded to the humanitarian toll. Issues of a humanitarian nature were never directly mentioned, perhaps because it is an ongoing conflict with potential to cause much painful soul-searching regarding national and ethnic priorities. At one point though, I did raise this question, and received a surprisingly terse comment. One participant simply said: "If they have money they can leave."

In future studies, a wider representation of the Yemeni population would be desirable. I was limited to students enrolled in a university in Guangdong Province, China. All participants had allegiances to pre-1990 South Yemen, and hailed from urban districts. It is also suggested that future studies include Yemeni women. There are far fewer Yemeni women than men studying in China, and I was unable to find women who would discuss their experiences and motivations for leaving Yemen. A future study conducted by a woman may alleviate this limitation.

\section{Notes}

Note 1. Malinowski, B. (1925). Magic, science, and religion and other essays. New York: Doubleday.

Note 2. Participants names are pseudonyms.

\section{Conflict of interests}

The authors declare that there is no conflict of interests regarding the publication of this paper.

\section{References}

Adler, M., Dunlop, W., Fivush, R., Lilgendahl, J., ..., \& Syed, M. (2017). Research methods for studying narrative identity: A primer. Social Psychological and Personality Science, 8(5), 519-527.

Adler, M., Lodi-Smith, J., Philippe, F., \& Houle, I. (2016). The incremental validity of narrative identity in predicting well-being: A review of the field and recommendations for the future. Personality and Social Psychology Review, 20(2), 142-175.

Altbach, P. (2007). Peripheries and centers: Research universities in developing countries. College and University Journal, 80(2), 3-8.

Becker, E. (1971). The birth and death of meaning: An interdisciplinary perspective on the problem of man. New York: Simon \& Schuster.

Becker, E. (1973). The denial of death. New York: Simon \& Schuster.

Benish-Weisman, M. (2009). Between trauma and redemption: Story form differences in immigrant narratives of successful and nonsuccessful immigration. Journal of Cross-Cultural Psychology, 40(6), 953-968.

Blumi, I. (2003). Thwarting the Ottoman Empire: Smuggling through the empire's new frontiers in Yemen and Albania, 1871-1910. International Journal of Turkish Studies, 9(1).

Brante, E. (2012). Stand together or fall alone: Narratives from former teachers. Narrative Works: Issues, Investigations \& Interventions, 2(2), 20-40.

Bury, M. (2001). Illness narratives: Fact or fiction? Sociology of Health \& Illness, 23(3), 263-285.

Clough, P. (2002). Narratives and fictions in educational research. Buckingham: Open University Press.

Darem, F. (2018). Yemen: Chaos, war and higher education. Retrieved from https://www.al-fanarmedia.org/2017/04/yemen-chaos-war-higher-education/

Gonzalez-Lopez, G. (2015). Family secrets: Stories of incest and sexual violence in Mexico. New York: NYU Press. 
Goodley, D. (2004). Gerry O'Toole: A design for life. In D. Goodley, R. Lawthom, P. Clough, \& M. Moore (Eds.), Researching life stories: Method, theory and analysis in a biographical age (pp. 3-14). London: Routledge Falmer.

Goodley, D., Lawthom, R., Clough, P., \& Moore, M. (Eds.). (2004). Researching life stories: Method, theory and analyses in a biographical age. London: Routledge Falmer.

Gopal, S. (2016). Born to trade: Indian business communities in Medieval and Early Modern Eurasia. New Delhi: Manohar.

Government of China. (2018). Growing number of foreign students choosing to study in China for a degree across multiple disciplines. Beijing: Government of The People's Republic of China. Retrieved from http://en.moe.gov.cn/News/Top_News/201804/t20180403_332258.html

Gray, D. (2001). Accommodation, resistance and transcendence: Three naratives of autism. Social Science \& Medicine, 53, 1247-1257.

Gregen, K., \& Gregen, M. (1986). Narrative form and the construction of psychological science. In T. Sarbin (Ed.), Narrative psychology: The storied nature of human conduct (pp. 22-24). New York: Praeger.

Gregen, K., \& Gregen, M. (1988). Narrative and the self as relationship. In L. Berkowitz (Ed.), Advances in experimental social psychology. San Diego: Academic Press.

Hammack, P. (2008). Narrative and the cultural psychology of identity. Personality and Social Psychology Review, $12,222-247$.

Hoskins, J. (2007). Who owns a life history? Scholars and family members in dialogue. In R. Waterson (Ed.), Southeast Asian Lives: Personal Narratives and Historical Experience. Singapore: National University of Singapore Press.

Klots, Y. (2011). The ultimate city: New York in Russian immigrant narratives. The Slavic and East European Journal, 55(1), 38-57.

Ladefoged, P. (1988). Hierarchical features of the International Phonetic Alphabet. Paper presented at the Fourteenth Annual Meeting of the Berkeley Linguistics Society, Berkeley.

Lieblich, A., Tuval-Mashiach, R., \& Zilber, T. (1998). Narrative research: Reading, analysis, and interpretation. Thousand Oaks: Sage.

Linde, C. (1993). Life stories: The creation of coherence. New York: Oxford University Press.

Martyn, H. L. (2018a). Narratives as catalysts for transformation and social action planning within the Hong Kong Indonesian migrant community. Asian Social Science, 14(6), 106-117.

Martyn, H. L. (2018b). Voices of Indonesian migrant workers at home and abroad. Asian Social Science, 14(8), 119-131.

McAdams, D., Diamond, A., de St. Aubin, E., \& Mansfield, E. (1997). Stories of commitment: The psychosocial construction of generative lives. Journal of Personality and Social Psychology, 72, 678-694.

McAdams, D., Josselson, R., \& Lieblich, A. (Eds.). (2001). Turns in the road: Narrative studies of lives in transition. Washington: American Psychological Association.

Moore, M. (2004). The death story of David Hope. In D. Goodley, R. Lawthom, P. Clough, \& M. Moore (Eds.), Researching life stories: Method, theory and analyses in a biographical age (pp. 26-39). London: Routledge Falmer.

Morris, D. (2017). Varieties of erotic experience: Five illness narratives. In D. Morris (Ed.), Eros and illness (pp. 107-134). Harvard University Press.

Murray, H. (2010). Not in this family: Gays and the meaning of kinship in postwar North America. University of Pennsylvania Press.

OECD. (2016). How many students study abroad? OECD Factbook 2015-2016: Economic, Environmental and Social Statistics.

Pavelko, S., \& Owens, R. (2017). Sampling utterances and grammatical analysis revised (SUGAR): New normative values for language sample analysis measures. Language, Speech and Hearing Services in Schools, $48(3)$.

Peters, M., \& Besley, T. (2018). China's double first class strategy. Educational Philosophy and Theory. 
Riessman, C. K. (2008). Narrative methods for the human sciences. Thousand Oaks, CA: Sage.

Riessman, C. K. (2015). Ruptures and sutures: Time, audience and identity in an illness narrative. Sociology of Health \& Illness, 37(7), 1055-1071.

The World Bank. (2008). Project Information Document (PID). Washington, D.C. Retrieved from http://documents.worldbank.org/curated/en/987271468334283631/PID0101113109.doc

The World Bank. (2015). Toward a new social contract. Washington D.C. Retrieved from $\mathrm{http}: / /$ www.worldbank.org/en/region/mena/publication/mena-economic-monitor

UNICEF. (2018). UNICEF: Education a major casualty of Yemen's war. Geneva. Retrieved from https://www.voanews.com/a/education-a-major-casualty-of-yemen-s-war/4573629.html

Waterson, R. (Ed.) (2007). South East Asian lives: Personal narratives and historical experience. Singapore: National University of Singapore Press.

Wen, W., \& Hu, D. (2018). The emergence of a regional education hub: Rationales of international students' choice of China as the study destination. Journal of Studies in International Education, 1(23).

White, M., \& Epston, D. (1990). Narrative means to thereputic ends. New York: Norton.

\section{Copyrights}

Copyright for this article is retained by the author(s), with first publication rights granted to the journal.

This is an open-access article distributed under the terms and conditions of the Creative Commons Attribution license (http://creativecommons.org/licenses/by/4.0/). 